\title{
The Mountain Fortresses of Rabana-Merquly in Iraqi-Kurdistan
}

The twin fortresses of Rabana-Merquly are situated on the western side of Mt. Piramagrun, one of the most prominent massifs in the Zagros Mountains. A defining feature of these adjoining settlements are their matching, approximately life-size rock-reliefs depicting a ruler in Parthian dress, which flank the entrance to both sites. Behind the perimeter walls several structures have been recorded including a citadel and a sanctuary complex. The combined intramural area is in excess of 40 hectares. Based on the style of relief sculptures, and the material culture of their associated intramural settlements, occupation is dated to the early first millennium A.D. Investigations at Rabana-Merquly are a collaboration between Heidelberg University and the Sulaymaniyah Directorate of Antiquities. This talk gives an overview of the main fieldwork results to date, emphasizing the relationship between the fortified settlements and the wider landscape of the central Zagros highlands. 